\title{
IMPLEMENTASI SUPERVISI PENDIDIKAN DALAM MENINGKATKAN PROSES PEMBELAJARAN
}

\author{
Ade Angriani Hasta \\ Email : adeangriani.aa@gmail.com
}

\begin{abstract}
ABSTRAK
Pada dasarnya kegiatan supervisi disekolah dilakukan oleh kepala sekolah atau yang biasa disebut sebagai supervisor, sebab sebagai pimpinan tertinggi disekolah tersebut ia harus mampu melakukan berbagai kegiatan diantaranya yaitu melakukan pengawasan dan pengendalian untuk meningkatkan kinerja para guru disekolah yang ia pimpin. Tujuannya yaitu untuk membantu mengembangkan kemampuan guru dalam mencapai tujuan pembelajaran yang dirancang bagi peserta didiknya. Kegiatan supervisi ini dilakukan untuk mencegah terjadinya penyimpangan yang dilakukan oleh guru dan agar ia dapat lebih profesional dalam melakukan pekerjaannya sebagai seorang pendidik. Melalui supervisi yang dilakukan kepala sekolah diharapakan kualitas akademik yang dilakukan guru dapat menjadi lebih meningkat. Dan pengembangan kemampuan dalam hal ini bukan hanya ditekankan pada peningkatan pengetahuan dan keterampilan mengajar guru tetapi juga pada peningkatan komitmen, kemauan atau motivasi guru, sebab dengan meningkatkan kamampuan dan motivasi guru tentu akan berpengaruh terhadap peningkatan kualitas belajar nantinya.
\end{abstract}

Kata Kunci : Supervisi Pendidikan, Kepala Sekolah, Guru

\section{PENDAHULUAN}

Pendidikan merupakan usaha sadar yang sengaja dirancang untuk mencapai suatu tujuan yang telah ditetapkan sebelumnya. Dengan adanya pendidikan dapat meningkatkan kualitas sumber daya manusia. Dan salah satu caranya yaitu dengan melakukan proses pembelajaran disekolah. Pendidikan tentu sudah ada setiap negara namun kualitas pendidikan dari setiap negara tentu berbeda - beda.

Dalam usaha meningkatkan kualitas pendidikan tersebut, tentu kita terlebih dahulu harus meningkatkan sumber daya pendidik dan tenaga pendidikan yang ada disekolah. Rendahnya prestasi belajar peserat didik berkaitan dengan kemampuan guru dalam mengelola pembelajaran yang rendah. Guru sebagai tenaga pendidik merupakan komponen sumber daya manusia pertama yang harus dibina dan dikembangkan secara terus menerus. Sebab ia memiliki potensi yang dapat digunakan untuk mengembangkan kemampuan peserta didik nantinya. Selain itu, masyarakat juga telah mempercayai dan menyerahkan anak - anak mereka untuk didik oleh guru, karena mereka meyakini bahwa guru merupakan tenaga profesional dalam kegiatan pendidikan. Namun, seringkali banyak faktor yang dapat menghambat guru dalam mengembangkan potensinya secara potensial. Dan faktor itu seperti, kemampuannya dalam melakukan proses belajar mengajar, ataupun sarana dan prasaran pendidikan yang tidak dapat ia kelola dengan maksimal. 
Maka dari itulah sangat diperlukannya kegiatan supervisi ini sebab dengan dilakukannya kegiatan supervisi pendidikan dapat meningkatakan kinerja guru dalam proses belajar mengajar yang ia lakukan nantinya. Sehingga ia dapat mengimplementasikan kemampuan yang ia miliki kepada peserta didik. Dan tingkat keberhasilan dari supervisi yang dilakukan itu sendiri dapat diukur atau dilihat dari peningkatan prestasi belajar peserta didik. Apabila prestasi belajar peserta didik meningkat maka dapat dikatakan bahwa supervisi yang dilakukan telah berhasil. Sebaliknya, jika tidak adanya perubahan terhadap prestasi belajar peserta didik maka supervisi yang dilakukan tidak berhasil.

Berdasarkan uraian diatas, permasalahan dalam tulisan ini adalah (1) Bagaimana konsep dasar supervisi pendidikan itu sendiri ? (2) Bagaimana pengimplementasian supervisi pendidikan dalam meningkatkan proses pembelajaran ? Dan tujuan dari penulisan ini adalah (1) Untuk mengetahui konsep dasar supevisi pendidikan. (2) Untuk mengetahui bagaimana implementasi supervisi pendidikan dalam meningkatkan proses pembelajaran.

\section{PEMBAHASAN}

\section{Pengertian Supervisi Pendidikan}

Supervisi sebagai suatu proses untuk menerapakan pekerjaan yang telah dilaksanakan, menilai dan mengoreksinya dengan maksud agar pelaksanaan supervis sesuai dengan tujuan yang telah ditetapkan.

Supervisi merupakan suatu bantuan yang dilakukan dalam pengembangan situasi belajar yang lebih baik. Artinya yaitu, layanan supervisi tersebut meliputi keseluruhan situasi belajar mengajar (materi, teknik, metode, pendidik, peserta didik dan lingkungan). Maka situasi belajar ini yang perlu diperbaiki dan ditingkatkan melalui kegiatan supervisi yang dilakukan oleh kepala sekolah. Sehingga kegiatan supervisi tersebut mecakup semua aspek dari penyelenggaraan pendidikan dan pengajaran. Supervisi yang diterapkan pada saat ini tidak hanya pembimbingan dan pelatihan profesional guru, melainkan juga memfasilitasi pengembangan profesional guru secara berkelanjutan sesuai dengan tuntutan perkembangan teknologi, ilmu pengetahuan dan kehidupan sosial masyarakat. (Sabandi, 2013)

Supervisi pendidikan merupakan suatu rangkaian kegiatan yang dilakukan kepada kepala sekolah, pendidik maupun tenaga kependidikan untuk mengembangakan kemampuan mereka dalam mengelola sekolah. Karena situasi belajar mengajar disekolah akan lebih baik tergantung kepada keterampilan supervisornya sebagai seorang pemimpin. Atau juga dapat dikatakan bahwa supervisi pendidikan merupakan kegiatan pembinaan yang dilakukan kepada seluruh staf sekolah agar mereka dapat meningkatkan kemampuan untuk mengembangkan situasi belajar mengajar yang lebih baik.

Glatthorn dalam bukunya juga menjelaskan bahwa supervisi juga diartikan sebagai serangkaian kegiatan yang dibentuk untuk mengembangkan proses belajar mengajar menjadi lebih baik (Kadarwati, 2016).

Jadi dapat disimpulkan bahwa, dengan adanya supervisi menjadikan situasi pembelajaran yang terjadi di sekolah menjadi lebih baik sehingga dapat mencapai tujuan pendidikan nasional. Dengan kata lain supervisi merupakan usaha sadar pembinaan yang dilakukan kepada staf pendidikan terutama guru ke arah perbaikan proses pembelajaran, diutamakan untuk meningkatkan kemampuan mengajar guru dikelas dengan cara kooperatif antara kepala sekolah dengan para guru. Kegiatan supervisi disekolah yang dilakukan oleh kepala sekolah selaku supervisor, akan dapat mengarah pada terciptanya suasana kerja yang 
harmonis, dimana para guru dapat merasa aman dan bebas dalam mengembangkan potensi dan daya kreasinya dengan penuh tanggung jawab.

\section{Implementasi Supervisi Pendidikan dalam Meningkatkan Proses Pembelajaran}

Untuk melakukan pengimplementasian supervisi pendidikan dalam meningkatkan proses pembelajaran, maka kepala sekolah selaku supervisor dapat melakukan hal - hal berikut ini, yaitu :

1. Penyusunan Program Supervisi Pendidikan

Dalam hal ini kepala sekolah dapat melibatkan wakil kepala sekolah serta para pendidik untuk melakukan penyusunan program supervisi pendidikan. Dan penyusunan serta pelaksanaan programnya ini dapat dilakukan pada awal tahun ajaran agar program kegiatan supervisi dapat diintegrasikan dalam setiap kegiatan sekolah secara komprehensif. Kegiatan supervisi ini dilakukan secara berkesinambungan atau terus menerus. Seperti pada awal tahun ajaran, setiap awal semester dan pada saat berlangsungnya proses pembelajaran. Kemudian evaluasi programnya dilakukan pada tiap akhir semeter ganji dan semester genap agar dapat diketahui sejauh mana pencapaian program supervisi yang telah dilaksanakan

Kepala sekolah menyusun program terlebih dahulu mengenai jadwal kegiatan yang terdiri dari tanggal dimulai pelaksanaannya sampai akhir, alat yang diperlukan, tujuan yang ingin dicapai, rancangan untuk pengembangan kemampuan profesioanal guru, meningkatkan motivasi kinerja guru dan bagaimana cara agar supervisi dengan baik.

Program yang telah disusun dapat dijadikan sebagai prioritas kegiatan sebelum proses belajar mengajar berlangsung, karena itu merupakan bagian dari tugas yang harus dilaksanakan kepala sekolah selaku supervisor disekolah tersebut.

Pelaksanaan supervisi yang dilakukan oleh kepala sekolah adalah dengan teknik humanistik bukan mencari - cari kesalahan, tetapi sungguh - sungguh membantu para pendidik untuk dapat bekerja lebih bagus dan terarah dalam melaksanakan tugasnya. (Suryani, 2016)

Kepala sekolah sebagai penanggung jawab pendidikan di tingkat sekolah memiliki kewenangan dan keleluasaan dalam mengembangkan berbagai program sekolah, mengelola dan mengawasinya, serta mengatur segenap sumber daya sekolah yang ada, yang dapat dimanfaatan bagi peningkatan mutu dan kinerja sekolah (Kadarwati, 2016)

2. Pemilihan Teknik Supervisi

Supervisor dapat memilih teknik yang akan dia gunakan dalam supervis yang ia lakukan seperti teknik kunjungan kelas dan teknik individual.

a) Teknik Kujungan Kelas

Supervisi dengan teknik ini bertujuan untuk memperoleh data mengenai keadaan sebenarnya selama guru melakukan kegiatan pembelajaran dikelas. Teknik ini juga dpat berfungsi sebagai alat untuk mendorong guru agar mau dan mampu meningkatkan proses pembelajaran dikelas sehingga motivasi dan hasil belajar peserta didik dapat meningkat dan menjadi lebih baik (Kadarwati, 2016)

Purwanto mengemukakan bahwa supervisi dengan teknik kunjungan kelas ini maksudnya yaitu kunjungan sewaktu - waktu yang dilakukan oleh kepala sekolah atau supervisor untuk melihat atau mengamati guru yang sedang melakukan kegiatan belajar mengajar dikelas. Suhertian menyatakan bahwa teknik supervisi perkunjungan kelas adalah Kepala Sekolah atau supervisor datang ke kelas untuk melihat cara guru mengajar di kelas (Kadarwati, 2016)

Teknik ini merupakan teknik yang paling mudah dan sering dilakukan oleh kepala sekolah untuk melihat dan mengamati para guru yang sedang melakukan 
proses pembelajaran dikelas, dengan tujuan untuk memperbaiki dan meningkatkan kompetensi profesional para guru dalam proses pembelajaran dikelas.

Tujuan umum dari teknik ini dapat dikelompokkan menjadi dua bagian yaitu pertama untuk mengetahui perilaku guru dalam segi - segi tertentu atau bersifat khusus dan yang kedua yaitu untuk mendapatkan informasi tentang masalah tertentu yang berguna bagi perbaikan pendidikan.

b) Teknik Perorangan (Individual)

Teknik perorangan (individual), yaitu suatu teknik supervisi yang dilaksanakan untuk seorang guru secara individual atau dengan kata lain kegiatan supervisinya dilakukan secara perseorangan. Kegiatan ini dapat terjadi di dalam kelas maupun di luar kelas. Supervisi yang dilakukan disini hanyalah dihadapkan pada seorang guru, agar hasil dari supervisi akan diketahui dari kualitas pembelajaran yang dilakukannya.

Teknik individual antara guru dengan supervisornya ini sangat membantu guru dalam memperbaki sistem pembelajaran yang lebih baik. Tinggi rendahnya kemampuan profesional gurudalam Proses Belajar Mengajar (PBM) tergantung pada usaha usaha kepala skolah dalam membina para pendidiknya. Maka dari itu, kepala skolah harus melaksanakan supervisi terhadapa pendidik untuk mengetahui tingkat profesionalnya meningkat atau menurun, malas atau tidak, disiplin atau tidak dan sebagainya (Suryani, 2016)

Maka dapat disimpulkan bahwa pengaruh supervisi pendidikan yang dilakukan kepala sekolah terhadap pendidik, maupun seluruh staf pendidikan dalam meningkatkan proses belajar mengajar sangat besar.

\section{PENUTUP}

\section{Kesimpulan}

Dari pembahasan pada tulisan ini dapat disimpulkan bahwa, Supervisi pendidikan merupakan suatu rangkaian kegiatan yang dilakukan kepada kepala sekolah, pendidik maupun tenaga kependidikan untuk mengembangakan kemampuan mereka dalam mengelola sekolah. Karena situasi belajar mengajar disekolah akan lebih baik tergantung kepada keterampilan supervisornya sebgai sorang pemimpin. Atau juga dapat dikatakan bahwa supervisi pendidikan merupakan kegiatan pembinaan yang dilakukan kepada seluruh staf sekolah agar mereka dapat meningkatkan kemampuan untuk mengembangkan situasi belajar mengajar yang lebih baik. Dengan adanya supervisi menjadikan situasi pembelajaran yang terjadi di sekolah menjadi lebih baik sehingga dapat mencapai tujuan pendidikan nasional

Pegimplementasian supervisi pendidikan untuk meningkatkan proses pembelajaran dapat diawali dengan penyusunan program supervisi yang dilakukan pada awal tahu ajaran. Kemudian dilanjutkan dengan pelaksanaannya yang dilakukan pada setiap awal semester dan akhir semester saat kegiatan proses belajar mengajar sedang berlangsung.

Kemudian pelaksanaannya dapat dilakukan dengan teknik kunjungan kelas, teknik perseorangan (Individual) dan penyusunan penyusunan laporan tindak lanjut supervisi tersebut. Pelaksanaan supervisi yang dilakukan oleh kepala sekolah adalah dengan teknik humanistik bukan mencari - cari kesalahan, tetapi sungguh - sungguh membantu para pendidik untuk dapat bekerja lebih bagus dan terarah dalam melaksanakan tugasnya. Kepala sekolah melakukan supervisi terhadap semua staf pendidikan sekolah. Dan pelaksanaan supervisi yang dilakukan kepala sekolah hendaknya lebih menekannkan kepada pembinaan 
kemampuan guru dalm mengelola pembelajaran. Sehingga nantinya akan terjadi peningkatan kualitas dan prestasi belajar peseta didik, yang menandakan bahwa supervisi yang dilakukan oleh kepala sekolah telah berhasil.

\section{Saran}

Supaya dengan adanya tulisan ini dapat dapat membantu pembaca dalam memahami pengiplementasian supervisi. Dan kami sebagai seorang pendidik atau calon pendidik dapat lebih memahami juga bagaimana pengimplementasian supervisi tersebut. Karna bukan tidak mungkin suatu saat kita juga kan terlibat secara langsung dengan kegiatan supervisi disekolah nantinya.

\section{REFERENSI}

Kadarwati, A. (2016). Peningkatan Kualitas Pembelajaran Melalui Supervisi Akademik ...103 |. Jurnal Studi Sosial, 1(2), 103-120. Retrieved from ejournal.unipma.ac.id/index.php/gulawentah/article/download/1034/919

Sabandi, A. (2013). SUPERVISI PENDIDIKAN UNTUK PENGEMBANGAN PROFESIONALITAS GURU BERKELANJUTAN. Pedagogik, Jurnal Ilmiah Ilmu Pendidikan, XIII(2), 1-9. Retrieved from http://ejournal.unp.ac.id/index.php/pedagogi/article/view/4275

Suryani, C. (2016). Implementasi Supervisi Pendidikan Dalam Meningkatkan Proses Pembelajaran Di Min Sukadamai Kota Banda Aceh. Jurnal Ilmiah Didaktika, 16(1), 23. https://doi.org/10.22373/jid.v16i1.585 